\title{
The metal and textile industry in Romania
}

\section{Current economic situation}

The world financial downturn has had a highly negative impact on Romania's economic activity, which has decreased much sharper than projected due to a combination of an unfavourable external environment and a faster retrenchment of domestic demand. GDP decreased by $7.1 \%$ in 2009 and by $2.4 \%$ year-on-year in the first half of 2010; whereas in 2008 it had risen by $7.1 \%$. For 2010 as a whole, GDP was projected on the negative side, at $-1.9 \%$, before switching into growth in 2011 , at a $1.5 \%$ increase rate.

Until the crisis, GDP growth averaged 6.2\% between 2001 and 2006, based primarily on consumption and investment. The unsustainable growth in consumption was determined by excess demand, which reached $15.7 \%$ of GDP in 2008, high wage increases and rising non-governmental domestic credit. Easy access to credit, together with the anticipation of higher household earnings, saw domestic credit growing by $56 \%$ in real terms at the beginning of 2001. Domestic credit is still relatively low in terms of its share of GDP, amounting to only $41 \%$ of GDP in 2009, compared to the values observed in other developed economies, but its pace of expansion was very high. In this respect, Romania's National Bank strengthened monetary policies and increased the benchmark policy rate to $10.25 \%$ by the end of 2008 , as well as setting the reserve requirements ratio and adopting a string of prudential measures aimed at limiting both household debt exposure and bank lending.

The increasing inflows of foreign capital, driven by high interest rates and potential gains in the property market, led to a continuous appreciation of the domestic currency, the RON. In consequence, imports rose faster than exports, widening the current account deficit to $-12.3 \%$ at the end of 2008 . The budget deficit increased from $-0.8 \%$ of GDP in 2005 to $-5.4 \%$ at the end of 2008 , mainly due to the pro-cyclical fiscal policy. With government revenues boosted by an overheated economy, government spending rose in areas which were less productive, especially public sector wages and consumption.

In April 2009, the government approved the Letter of Intent negotiated with the International Monetary Fund (IMF) for a loan of $€ 19.95 \mathrm{bn}$. This comprised $€ 12.95 \mathrm{bn}$ from the IMF, $€ 5 \mathrm{bn}$ from the European Commission and $€ 1 \mathrm{bn}$ each from the World Bank and the European Bank for Reconstruction and Development (EBRD). The country subsequently managed to avoid any potential shortfalls in financing its external and internal deficits. Moreover, the IMF programme detailed the necessary changes which needed to be implemented by fiscal authorities in order to make fiscal policy more transparent and accountable. The rapid response of international authorities were paramount in staving off a foreign capital outflow.

Romania's biggest issue is the budget deficit, on which it has a target of $6.8 \%$ of GDP in 2010. In order to meet this target, the government took a set of austerity mea- 
sures, which were unpopular, as a result of the delay in encompassing a timely plan with anti-crisis measures since 2009 was an election year.

In May 2010, after a visit from IMF evaluators, President Băsescu informed the nation, without any consultation, that salaries paid from state public funds would be slashed by $25 \%$, while pensions, unemployment benefits and other social security entitlements would be cut by $15 \%$. The government then issued Act 118/29 in June 2010, which took effect from 2 July. This set out a series of provisions lasting until 31 December 2010:

- a $25 \%$ reduction in the gross salaries of public workers, including fringe benefits and bonuses

- a $25 \%$ reduction in other entitlements due to teachers and to defence, law enforcement and national security personnel, as well as on monthly food allowances, subsidies for rent and other benefits granted to scientists and artists

- a $15 \%$ reduction in unemployment benefits, severance pay payable under collective dismissal schemes and in child benefit

- elimination of holiday tickets, compensations and allowances for retirement or decommissioning from active military service

- an increase in VAT from $19 \%$ to $24 \%$.

The effects of the financial crisis on the Romanian economy

The effects of the financial crisis started to be felt in the Romanian economy during Q4 2008.

The perspective of a sudden stop to capital inflows implied that finding rapid alternatives for financing lines was a priority. Thus, in early 2009 the authorities turned to the IMF. In March 2009, the Romanian government concluded talks on a $€ 19.5 \mathrm{bn}$ stand-by agreement with a group of international institutions led by the IMF.

The slowdown in global demand had profound implications for the Romanian economy. Unable to sustain its demand internally, the Romanian economy plunged into recession. In 2009, private consumption dived by $9.2 \%$ year-on-year as the shock to real incomes influenced household purchasing patterns. Net exports adjusted sharply, contracting from around $15 \%$ of GDP in 2007 to a little over $5 \%$ of GDP at the end of 2009.

Gross fixed capital formation, a measure of how fast the capital stock is being replaced, fell by almost one-quarter compared to 2008 . The construction sector suffered the most, with activity falling by more than $17 \%$ year-on-year. Activities in the wholesale and retail sectors were cut by $11.2 \%$, while industrial output decreased by $4.3 \%$ compared to 2008 .

In 2009, inflation $(4.74 \%)$ fell outside the NBR inflation target band for the third year in a row.

Throughout 2009, the monetary policy stance was mostly loose but, overall, rather prudent. The economy was contracting abruptly, but the NBR's benchmark interest rate was only gradually reduced over the year, from $10.25 \%$ to $6.25 \%$. With inflation falling, real interest rates in the economy were too high to help firms ease their bor- 
rowing needs. Inflation was a little off the NBR targets in 2009 but, in 2010, due to the July VAT increase, prices rose by $7.77 \%$ year-on-year in September.

Forced to adjust, companies laid off workers, which put pressure on average wage growth, sending it into negative territory at the beginning of 2010. It is worth mentioning that nominal wages had been growing at rates above $20 \%$ for the previous two decades. The dramatic fall in wages reduced one important source of inflation pressure and, if sustained, could raise competitiveness.

The prudent approach to monetary policy is also explained by the attention the NBR paid to the evolution of the exchange rate. The NBR targets inflation, but concerns about large swings in the exchange rate made the NBR adopt a proactive stance through foreign exchange market interventions.

Fiscal policy also played a large part in the deepening of the existing macroeconomic imbalances. In the last quarter of 2008 , the budget deficit rose to $5.4 \%$ of GDP, mainly due to the substantially higher than planned current spending on public wages and social transfers. Most of these occurred in October 2008, prior to the parliamentary elections. The government also had over-optimistic budget revenue projections, since it declared that the financial crisis would not affect the country.

2010 was a harsh year in terms of the austerity measures taken by the government to fulfil the IMF stand-by agreement, which was to have a severe impact on demand in the second part of the year. In the first half, industry saw a positive outcome: in July 2010 compared to July 2009, the gross index of production industry increased by $3.4 \%$ due to the increased outout in electricity production and supply, and in gas, steam and air conditioning $(+3.5 \%$ each $)$; and in industry quarrying $(1.3 \%)$.

\section{The macroeconomic policy challenges ahead}

In the medium-term, economic policies should be geared towards achieving economic stability and, implicitly, to fulfil the Maastricht criteria. Current plans foresee the adoption of the Euro in 2015. For this to happen, Romania would need to enter the Exchange Rate Mechanism two years earlier. That leaves an extremely short period of time, less than three years, to resolve current macroeconomic imbalances.

The most important challenge is to put fiscal policy on a sustainable track.

The challenge for the Romanian labour force is quite high: the latest letter sent from the government to the IMF regarding public lay-offs stated that 25000 public workers had been laid-off; 75000 more would go in 2010; and another 15000 in 2011. Total public lay-offs will total 115000 workers, also putting pressure on the unemployment rate and on demand. In September 2010, the unemployment rate stood at 7.35\%.

Regaining investment grade status should be a priority for the Romanian authorities. This would translate not only into lower borrowing costs, but would also show a more positive image of the Romanian economy. Recently, Standard \& Poor's revised Romania's long-term ratings from negative to stable. The rating revision reflects the government's progress in pursuing its budget reform programme. This could open the door for a reassessment of Romania's overall risk, which would place the country in the investment grade category. 
Repayment of the IMF loan in the years ahead could create strains in the foreign exchange market if fiscal policy was not on a sustainable path and macroeconomic stability remained uncertain. To this extent, the Romanian government is looking to extend the current agreement or to submit to a preventive agreement in order to repay its debt. Achieving macroeconomic stability and bringing the budget deficit under control would require a strong commitment from the authorities over the next two-three years. Romania cannot enter EMU with an economy in which structural imbalances persist; the risk would be far too great and could lead to a loss of competitiveness. Thus, government expenditure will be severely constrained over the next couple of years. And, if the Financial Responsibility Law is adopted - as it should be according to the IMF memorandum agreement - government expenditure growth would not be allowed to exceed GDP growth. In addition, multi-annual budgeting would provide a more transparent, coherent and forward-looking mechanism for conducting fiscal policy.

\section{The metal and textile industries in Romania}

\section{Sectoral structure}

Metals and textiles are traditional activities in Romania. The manufacturing sector is dominated by machine building, metals, chemicals and textiles, making products which had to turn from supplying the domestic market to finding new export-oriented customers. Much of the equipment left is outdated, as it was at the fall of communism. Therefore, investment is a key issue in the manufacturing industry and for which aim the state has privatised most state-owned firms, even the biggest, most strategic firms.

During the 1990s, many of the largest firms were divided into smaller units in an effort to increase efficiency and hasten their privatisation. The disruption was enormous and firms active in an isolated market found it tough to raise their production to the standards required for export. However, there has been some recovery in the sector. Romanian manufacturing industry is dominated by multinational companies, much of the sector being populated by the plants of foreign firms.

The textile and footwear industries have been among the most successful in the 2000s, as western European and US clothes makers sub-contract work to Romanian firms. The result is that textile exports accounted for $10.5 \%$ of 2008 exports, dipping to $10 \%$ in 2009 . However, such work depends on low wages and mostly encourages the lohn system. Romania is concerned to progress from sub-contracting to selling its own clothing designs. The gross monthly wage in the textiles sector is around $€ 260$.

Romania is one of the most important markets in south-east Europe regarding the automotive industry. Renault and Ford are very active investors in the country, respectively owning Dacia and Daewoo, the local motor vehicles manufacturing companies. The manufacture of motor vehicles, trailers, semi-trailers and other transport equipment is comprised of 862 companies (2008), where the main production is represented by semi-fabricated parts. In 2009 the total number of passenger cars, commercial vehicles and buses amounted to 296498 , an increase of $12 \%$ compared to 2008. The total turnover of the sectors amounted to approximately $€ 7700 \mathrm{~m}$ ( $6 \%$ of GDP).

The metallurgical industry is one of the oldest industries in Romania. The metals sector enjoyed a boom up to 2008 thanks to high world prices although, as the crisis 
affected Romania, production decreased by almost $50 \%$ in 2009 . The lower production led to a lower export ratio, from $14.6 \%$ in 2008 to $10 \%$ in 2009 . The gross monthly wage in this sector is higher than the medium Romanian wage, reaching almost $€ 420$. However, Romania is an important exporter of metallic construction products, having high quality products and competitive prices. The sector plays an important role in the economy of the country; total turnover accounts for $7 \%$ of GDP (7 505 companies in 2008). Manufacturers are scattered all over the country; however, the most important clusters are located in Hunedoara, Galați, Caraş-Severin and Târgovişte.

The machine building industry was created and developed in Romania after World War II and now is one of the most important sectors in manufacturing industry. The most important branches are electric and electronic equipment, machine tools and technological aggregates, while the most important trading partners are Germany and Italy. The total number of enterprises in the manufacture of computer, electronics, optical products, electrical equipment, machine tools, repair and installation amounts to 4766 in 2008; their turnover accounting for $6 \%$ of GDP.

Regarding computer programming, consultancy and information service activities, 9720 enterprises were active on the market in 2008 although no financial data is available.

Global metals demand is likely to be more dependent on growth in developed economies in the next phase of the recovery. The construction, automotive and capital goods sectors - key to the consumption of base metals - remains weak in most industrialised regions. Should the sovereign debt crisis prompt further austerity measures and/or a credit crisis, construction spending will remain at risk. Persistent high unemployment will impede growth in the automotive and durable goods sectors.

\section{Growth rates of industrial production per sector}

In the last years, industrial production indexes have decreased sharply, mainly due to the effects of the crisis and privatisation/restructuring. However, in manufacturing industry, the index recovered in 2010 after a substantial decrease in 2008 . The largest decline was in the metal industry, where the industrial production index decreased to 55 in $2008(2005=100)$, having reached a value of 98.4 in 2007.

The textile industry was also affected: the production of textiles decreased to 79.3 in 2009 while clothes manufacturing declined to 50.5 . 
Table 1 - Industrial production indices by industrial activity - working day and seasonally adjusted series

\begin{tabular}{|l|c|c|c|c|c|c|c|c|c|c|c|}
\hline & $\mathbf{2 0 0 0}$ & $\mathbf{2 0 0 1}$ & $\mathbf{2 0 0 2}$ & $\mathbf{2 0 0 3}$ & $\mathbf{2 0 0 4}$ & $\mathbf{2 0 0 5}$ & $\mathbf{2 0 0 6}$ & $\mathbf{2 0 0 7}$ & $\mathbf{2 0 0 8}$ & $\mathbf{2 0 0 9}$ & $\begin{array}{c}\text { July } \\
\mathbf{2 0 1 0}\end{array}$ \\
\hline TOTAL & 105.3 & 100.7 & 100.7 & 102 & 103.7 & 106.2 & 117.6 & 125.9 & 108.8 & 119 & 122.8 \\
\hline Manufacturing & 104.1 & 98.5 & 102.6 & 101.6 & 103.8 & 103.4 & 121.7 & 132 & 110.7 & 123.2 & 128 \\
\hline $\begin{array}{l}\text { Manufacture of } \\
\text { textiles }\end{array}$ & 117 & 108 & 127.2 & 108 & 115.9 & 96.9 & 105.9 & 93.4 & 88.2 & 79.3 & 73.9 \\
\hline $\begin{array}{l}\text { Manufacture of } \\
\text { clothing }\end{array}$ & 120.1 & 131.1 & 128.6 & 127.3 & 109.8 & 101.5 & 98.4 & 78.9 & 62.9 & 50.5 & 53.8 \\
\hline $\begin{array}{l}\text { Manufacture of } \\
\text { basic metals }\end{array}$ & 80.4 & 91.9 & 107.7 & 92.2 & 109.9 & 98.7 & 103.2 & 98.4 & 55 & 66.3 & 74.2 \\
\hline $\begin{array}{l}\text { Manufacture of } \\
\text { fabricated } \\
\text { metal products, } \\
\text { except } \\
\text { machinery and } \\
\text { equipment }\end{array}$ & 150.2 & 124.3 & 116.6 & 132.7 & 103 & 107.1 & 142.6 & 168.7 & 161.4 & 134.9 & 146.5 \\
\hline $\begin{array}{l}\text { Manufacture of } \\
\text { computer, } \\
\text { electronic and } \\
\text { optical } \\
\text { products }\end{array}$ & 139.6 & 110.5 & 106 & 148 & 180.3 & 92.4 & 170.3 & 128.7 & 126.8 & 92.3 & 115.3 \\
\hline $\begin{array}{l}\text { Manufacture of } \\
\text { electrical } \\
\text { equipment }\end{array}$ & 87.2 & 83 & 93.5 & 94.3 & 95.3 & 112.1 & 158.8 & 143.2 & 118.4 & 204.3 & 253.9 \\
\hline $\begin{array}{l}\text { Manufacture of } \\
\text { machinery and } \\
\text { equipment } \\
\text { n.e.c. }\end{array}$ & 134.2 & 141.1 & 140.4 & 122.9 & 115.6 & 99 & 128.3 & 144.9 & 131.3 & 92.6 & 102.6 \\
\hline $\begin{array}{l}\text { Manufacture of } \\
\text { motor vehicles, } \\
\text { trailers and } \\
\text { semi-trailers }\end{array}$ & 48.9 & 49.6 & 54.4 & 63.8 & 86.9 & 114.1 & 113.2 & 159.6 & 65.3 & 184.9 & 194.1 \\
\hline $\begin{array}{l}\text { Manufacture of } \\
\text { other transport } \\
\text { equipment }\end{array}$ & 107.8 & 88 & 93.7 & 99 & 98.1 & 104.7 & 117.5 & 122.9 & 132.7 & 101.1 & 68.1 \\
\hline
\end{tabular}

Source: Tempo database, National Institute of Statistics

The industrial indices show how Romania's economy has almost reverted to its 2000 status: most manufacturing sectors have a similar index to what they had over ten years ago. Overall, the industrial production index has increased, although it was mostly 
helped by high-rising sectors like the manufacture of electrical equipment and the manufacture of motor vehicles, trailers and semi-trailers; while the financial downturn has had a major impact on sectors like the manufacture of clothing, basic metals and the manufacture of other transport equipment.

\section{Sectoral specialisation}

In the textile industries, most companies work under the lohn or 'cut - make - trim' system under which Romanian companies supply labour and machinery while the customer supplies the raw materials, design and marketing. The textile industry depends on foreign demand, as almost $90 \%$ of production is exported. Therefore, in 2008 production decreased by almost half.

Before entering the European Union, Romania had to restructure its metallurgy industry, which involved privatising large plants the state could not manage efficiently - those which were almost on the verge of bankruptcy, receiving significant allocations of state aid and tax concessions. In return, Romania's total production was reduced overall by $2.05 \mathrm{~m}$ tonnes of finished product. The state aid ( $€ 1.2 \mathrm{bn})$ programme was concluded at the end of 2004, while the restructuring programme finished at the end of 2008.

\section{Employment structure}

\section{Breakdown and evolution per sector}

The number of people employed in manufacturing industry has decreased sharply since 2000, the highest rate of decline being registered in 2009 and 2010. Also, the share of employees in the manufacturing sector dropped as a share of all workers from $34 \%$ in 2000 to $23 \%$ in 2010 . Compared to 2000 , the number of employees in manufacturing industry in July 2010 had decreased by $38 \%$.

It is worth recording that all the industries studied had a reduction in the number of employees: the highest decrease, of $66 \%$, is seen in base metal manufacturing while the service-related sector - computer programming, consultancy and related activities, and information services activities - was affected strongly only in 2010 .

The evolution of employment in each sector is presented below. The number of employees at the end of the reference period represents employees with labour contracts for a definite or indefinite period of time, either full- or part-time (and including those with suspended work contracts) who were registered in the unit at the end of the reference period. Employees relocated abroad and those who hold more than one position, the main position being outside the reporting unit, are not included.

The textiles and clothing industry account for $17 \%$ of the manufacturing labour force while the other studied sectors account for $44 \%$. The highest number of employees was registered in the clothing sector and in the manufacture of motor vehicles, trailers and semi-trailers. 
Table 2 - Number of employees per sector

\begin{tabular}{|c|c|c|c|c|c|c|c|}
\hline & 2000 & 2005 & 2006 & 2007 & 2008 & 2009 & $\begin{array}{l}\text { July } \\
2010\end{array}$ \\
\hline TOTAL & 4646287 & 4790431 & 4910088 & 5162967 & 5232694 & 4879480 & 4247700 \\
\hline MANUFACTURING & 1586257 & 1468197 & 1441230 & 1439239 & 1352383 & 1128459 & 982400 \\
\hline Manufacture of textiles & 62010 & 44696 & 42052 & 38841 & 34753 & 28174 & 23600 \\
\hline Manufacture of clothing & 315865 & 303286 & 285009 & 247185 & 211140 & 173248 & 143500 \\
\hline $\begin{array}{l}\text { Manufacture of other } \\
\text { non-metallic mineral } \\
\text { products }\end{array}$ & 81444 & 60014 & 56264 & 57932 & 54570 & 41889 & 33800 \\
\hline $\begin{array}{l}\text { Manufacture of basic } \\
\text { metals }\end{array}$ & 94792 & 58248 & 53312 & 49905 & 49557 & 36452 & 32400 \\
\hline $\begin{array}{l}\text { Manufacture of } \\
\text { fabricated metal } \\
\text { products, except } \\
\text { machinery and } \\
\text { equipment }\end{array}$ & 81597 & 94818 & 98582 & 104927 & 102741 & 80284 & 67900 \\
\hline $\begin{array}{l}\text { Manufacture of } \\
\text { computer, electronic } \\
\text { and optical products }\end{array}$ & 25113 & 24784 & 25583 & 30726 & 27474 & 22132 & 20000 \\
\hline $\begin{array}{l}\text { Manufacture of } \\
\text { electrical equipment }\end{array}$ & 38404 & 39882 & 39521 & 43148 & 39325 & 33284 & 33000 \\
\hline $\begin{array}{l}\text { Manufacture of } \\
\text { machinery and } \\
\text { equipment n.e.c. }\end{array}$ & 133102 & 80648 & 74881 & 70069 & 68215 & 51587 & 47800 \\
\hline $\begin{array}{l}\text { Manufacture of motor } \\
\text { vehicles, trailers and } \\
\text { semi-trailers }\end{array}$ & 96290 & 102458 & 104629 & 117525 & 119510 & 110946 & 116400 \\
\hline $\begin{array}{l}\text { Manufacture of other } \\
\text { transport equipment }\end{array}$ & 37371 & 35112 & 34550 & 36802 & 41999 & 33598 & 27000 \\
\hline $\begin{array}{l}\text { Repair and installation } \\
\text { of machinery and } \\
\text { equipment }\end{array}$ & 39020 & 36121 & 35519 & 37990 & 33240 & 28180 & 24700 \\
\hline $\begin{array}{l}\text { Computer } \\
\text { programming, } \\
\text { consultancy and related } \\
\text { activities, and } \\
\text { information services } \\
\text { activities }\end{array}$ & 12165 & 21718 & 25889 & 33175 & 33074 & 34562 & 24500 \\
\hline
\end{tabular}

Source: Tempo database, National Institute of Statistics 


\section{Productivity developments}

The index of labour productivity per employee is calculated based on industrial production indices and the average number of employees for the industrial activity. The labour productivity index has increased overall, showing a better performance in terms of industrial sector.

The manufacturing sector, overall, reported a good outcome with a productivity index of $203.7 \%$. Considering the industrial production index, which regained in 2010 its level of 2000, and the decline of $35 \%$ in the number of employees, the results for labour productivity indicate the positive impact of restructuring processes on Romania's industry.

The highest productivity was achieved in the manufacture of electrical equipment $(292.2 \%)$, while the lowest was registered in the manufacture of other transport equipment.

Table 3 - Labour productivity indices

\begin{tabular}{|c|c|c|c|c|c|c|c|}
\hline \multirow{2}{*}{ Labour productivity indices $(2005=100)$} & \multicolumn{5}{|c|}{ Years } & \multirow[b]{2}{*}{$\begin{array}{c}\text { Dec } \\
2009\end{array}$} & \multirow[b]{2}{*}{$\begin{array}{l}\text { July } \\
2010\end{array}$} \\
\hline & 2000 & 2004 & 2006 & 2007 & 2008 & & \\
\hline INDUSTRY & 87.2 & 99.1 & 112.1 & 125.4 & 138.7 & 157.7 & 192.7 \\
\hline MANUFACTURING & 88.4 & 99.1 & 113.9 & 128.4 & 136.4 & 157.3 & 203.7 \\
\hline Manufacture of textiles & 83.5 & 103.2 & 98.2 & 116.9 & 112.8 & 131.3 & 135.7 \\
\hline Manufacture of clothing & 106.8 & 110.1 & 106.2 & 106.5 & 95.2 & 83.7 & 122.9 \\
\hline $\begin{array}{l}\text { Manufacture of other non-metallic mineral } \\
\text { products }\end{array}$ & 71.8 & 103 & 126.9 & 156.8 & 176 & 108.1 & 273.8 \\
\hline Manufacture of basic metals & 49.2 & 89.4 & 105 & 116.5 & 99.9 & 95.3 & 144.9 \\
\hline $\begin{array}{l}\text { Manufacture of fabricated metal products, except } \\
\text { machinery and equipment }\end{array}$ & 166.2 & 105.2 & 121.9 & 132.8 & 152.8 & 156.1 & 220.6 \\
\hline $\begin{array}{l}\text { Manufacture of computer, electronic and optical } \\
\text { products }\end{array}$ & 143.8 & 146.2 & 126.6 & 106.1 & 120.3 & 120.9 & 122.6 \\
\hline Manufacture of electrical equipment & 87.5 & 103.7 & 132.7 & 129.8 & 147.8 & 194.1 & 292.2 \\
\hline Manufacture of machinery and equipment n.e.c. & 93.1 & 109.2 & 114 & 152.8 & 155.6 & 149.1 & 169.1 \\
\hline $\begin{array}{l}\text { Manufacture of motor vehicles, trailers and semi- } \\
\text { trailers }\end{array}$ & 47.9 & 80.4 & 111 & 125.2 & 118.7 & 148.9 & 206.4 \\
\hline Manufacture of other transport equipment & 89.1 & 96.9 & 115 & 128 & 111.9 & 118.1 & 99.4 \\
\hline $\begin{array}{l}\text { Repair and installation of machinery and } \\
\text { equipment }\end{array}$ & 90.7 & 107.9 & 105.2 & 109.1 & 97.4 & 119.5 & 132.5 \\
\hline
\end{tabular}

Source: Tempo database, National Institute of Statistics 


\section{Labour costs - share of labour costs in value added}

Table 4 presents the trends in the labour costs per sector for enterprises.

The average monthly labour cost represents all the expenditures supported by the unit for the labour force, namely:

1. the gross amounts directly paid to employees (direct expenditure) from :

- the salary fund (including bonuses and payment in kind): i.e. the amounts paid for the work done (base salary; additions or indemnities as percentage or fixed amounts; other additions to base salary)

- the net profit and other funds (including payments in kind): bonuses and incentives from the net profit participation fund; payments in kind and financial aid; incentives; meal vouchers for employees

- the social insurance fund: indemnities for sickness leave; temporary incapacity for work; taking care of a sick child below three years old; and other allowances according to the labour contract.

2. other labour force expenditure of the unit (indirect expenditure):

- the contribution of the employer to unemployment social security, health social insurance, the risk and accident fund, social insurance left after the payment of rights granted to the employees

- expenditure on vocational training

- expenditure on nurseries and kindergartens, and cultural, educational and recreation services

- expenditure on meals and nourishment

- expenditure on reduction of the cost of rest and recuperation tickets

- expenditure on protective equipment

- expenditure on the transport of employees to and from the workplace

- expenditure on staff recruitment

- other labour force expenditure.

In real terms, the average monthly labour cost per employee increased by $67 \%$ in manufacturing industry, the highest increase being in the services sector (computer programming, consultancy and related activities, and information services activities), where the increase in 2009 was $103 \%$ on the 2005 level. The level of costs in 2000 underlines the discrepancies and the financial instability since CPI registered at the beginning of the decade was $145.7 \%$. The lowest increase was in the manufacture of computer, electronics and optical products.

Table 4 - Average monthly labour cost per employee, nominal terms RON

\begin{tabular}{|l|c|c|c|c|c|c|c|}
\hline $\begin{array}{l}\text { Average monthly labour } \\
\text { cost per employee, nominal } \\
\text { terms }\end{array}$ & $\mathbf{2 0 0 0}$ & $\mathbf{2 0 0 5}$ & $\mathbf{2 0 0 6}$ & $\mathbf{2 0 0 7}$ & $\mathbf{2 0 0 8}$ & $\mathbf{2 0 0 9}$ & $\begin{array}{c}\text { Staff yearly } \\
\text { expenditures for } \\
\text { employers (2008) }\end{array}$ \\
\hline TOTAL & 435 & 1310 & 1531 & 1835 & 2296 & 2425 & 92257086161 \\
\hline
\end{tabular}


The metal and textile industry in Romania

\begin{tabular}{|c|c|c|c|c|c|c|c|}
\hline $\begin{array}{l}\text { Average monthly labour } \\
\text { cost per employee, nominal } \\
\text { terms }\end{array}$ & 2000 & 2005 & 2006 & 2007 & 2008 & 2009 & $\begin{array}{c}\text { Staff yearly } \\
\text { expenditures for } \\
\text { employers (2008) }\end{array}$ \\
\hline MANUFACTURING & 389 & 1118 & 1275 & 1522 & 1821 & 2005 & 29161703169 \\
\hline Manufacture of textiles & 295 & 866 & 961 & 1161 & 1431 & 1609 & 596168947 \\
\hline $\begin{array}{l}\text { Manufacture of wearing } \\
\text { apparel }\end{array}$ & 280 & 797 & 870 & 1059 & 1237 & 1289 & 2902782209 \\
\hline $\begin{array}{l}\text { Manufacture of other non- } \\
\text { metallic mineral products }\end{array}$ & 441 & 1305 & 1537 & 1865 & 2216 & 2526 & 1426295754 \\
\hline Manufacture of basic metals & 638 & 1818 & 2217 & 2546 & 2805 & 2988 & 1705036780 \\
\hline $\begin{array}{l}\text { Manufacture of fabricated } \\
\text { metal products, except } \\
\text { machinery and equipment }\end{array}$ & 376 & 1199 & 1391 & 1602 & 1952 & 1968 & 2403580294 \\
\hline $\begin{array}{l}\text { Manufacture of computer, } \\
\text { electronic and optical } \\
\text { products }\end{array}$ & 544 & 1596 & 1789 & 2001 & 2244 & 2649 & 759498958 \\
\hline $\begin{array}{l}\text { Manufacture of electrical } \\
\text { equipment }\end{array}$ & 424 & 1229 & 1428 & 1645 & 1960 & 2308 & 1071783310 \\
\hline $\begin{array}{l}\text { Manufacture of machinery } \\
\text { and equipment n.e.c. }\end{array}$ & 427 & 1339 & 1548 & 1799 & 2286 & 2432 & 1847802142 \\
\hline $\begin{array}{l}\text { Manufacture of motor } \\
\text { vehicles, trailers and semi- } \\
\text { trailers }\end{array}$ & 441 & 1362 & 1575 & 1845 & 2151 & 2513 & 2948683824 \\
\hline $\begin{array}{l}\text { Manufacture of other } \\
\text { transport equipment }\end{array}$ & 592 & 1776 & 1983 & 2300 & 2787 & 3026 & 1337783903 \\
\hline $\begin{array}{l}\text { Repair and installation of } \\
\text { machinery and equipment }\end{array}$ & 485 & 1491 & 1664 & 1927 & 2176 & 2397 & 1028407859 \\
\hline $\begin{array}{l}\text { Computer programming, } \\
\text { consultancy and related } \\
\text { activities; Information } \\
\text { service activities }\end{array}$ & 798 & 1949 & 2490 & 3167 & 3861 & 4512 & \\
\hline
\end{tabular}

Source: Tempo database, National Institute of Statistics

\section{Impact of restructuring processes / privatisation}

After the fall of the communist regime, the Romanian economy underwent important structural changes which, in the first decade, caused a reduction of the contribution of industry to GDP formation from about $40 \%$ in 1990 to about $25 \%$ in 1999. During the 1990 s, privatisation was carried out slowly while the process is now almost complete. It was often seen in the press as a source of corruption at all levels. A major impact was seen in the reduced number of employees as restructuring programmes were adopted; nevertheless, labour productivity increased. 
A large number of loss-making enterprises were kept alive through government intervention, sheltering them from the rigours of market discipline and preventing them from adjusting to the increasingly competitive business environment. Delayed restructuring and an insistence on unrealistic conditions for privatisation in relation to market requirements caused a severe depreciation of the assets of many enterprises and wiped out the competitive advantages that they might originally have had. The actual worth of manufacturing equipment made redundant as a result of restructuring and privatisation is hard to estimate, but it is sufficient to note that, from 2000 to 2007, Romanian exports of scrap iron averaged $2 \mathrm{~m}$ tonnes a year. It is notable that some sectors (textiles, electrical equipment, shipbuilding) underwent deeper structural adjustments, which were made possible due to rapid privatisation and were able to attain a reasonable level of profitability.

\section{Investment}

In Romania, there are three branches which contribute significantly to investment formation and, according to a study conducted by the Ministry of Economy (a contribution of $79.5 \%$ in 2000 and $78.9 \%$ in 2007), these are: (NACE 33) Construction (45\% in 2000 and $49.3 \%$ in 2007); (NACE 23) Machinery and equipment $(23.5 \%$ in 2000 and $13.4 \%$ in 2007); and (NACE 28) Motor vehicles (10.9\% in 2000 and $16.3 \%$ in 2007). There is a significant increase of the share taken by the construction industry between 2000 and 2007 in the total amount of investment, as well as a sharp decline, over $10 \%$, in the share taken by the machinery and equipment sector. In the same period, however, the share of the vehicles sector in the volume of total investment has grown to exceed that of machinery and equipment.

\section{Investments per sector}

Gross investment in the manufacturing industry increased, in real terms, by $109 \%$ in 2008 compared to 2005. The highest increase in investment was in the non-metallic mineral products sector $(+254 \%)$, while the manufacture of electrical and optical equipment decreased by $33 \%$. Important investments were also made in the manufacture of transport equipment $(+109 \%)$.

Huge investments were allocated in the 2000 s as a result of privatisation. In the metal industry, the big companies owned by the state were working at dumping prices and therefore started to be unproductive. Major decisions were made to privatise the steel sector and companies like Alro Slatina, Ispat Sidex Galaţi, Siderurgica Hunedoara, COS Târgovişte, CS Reşiţa, Donasid Siderca Călăraşi were sold to private investors for very low prices, guaranteeing state facilities to the investors if they kept their promises to invest and create new jobs.

Sectors like the manufacture of base metals, motor vehicles and machinery are highly capital and energy intensive. They require huge investments, amortisation and modernisation costs. Therefore, the social capital per employee is much higher in such industries than it is in light industry or in the sector of repair and installation. In real terms, the indicator has increased significantly over time; by $156 \%$ in the manufacture of machinery and by $140 \%$ in the manufacture of base metals. 


\section{Foreign direct investment (per sector, origin)}

The Romanian business environment has improved significantly in recent years, driven in particular by EU accession. Between 2004 and 2006, several important reforms were undertaken, including a new Labour Code and the adoption of a policy of inflating targeting managed by the Central Bank. According to the Word Bank Doing Business report, Romania ranks 55th among 183 economies, second among south-east European economies.

According to the Romanian legislation in force, all investors enjoy the same rights and incur the same obligations, irrespective of their being Romanian or foreign citizens, residents or non-residents.

Foreign direct investment in Romania increased significantly in the past years up to 2009, when investment halved compared to 2008. Compared to 2000, FDI increased eight times in 2008. In the textiles and metal industry, FDI increased in nominal terms (2003-2008 available data), although their share in industry investment decreased considerably.

The global financial crisis has had a negative impact on reducing the output of many manufacturing sectors in Romania affecting mainly the automotive, construction, textiles and clothing, chemical and woodworking industries, etc. This, in turn, has resulted in job losses - the number of workers in manufacturing industry decreased by 334300 in July 2010 compared to December 2007 - as well as a decline in real wages.

\section{Table 5 - FDI (€m)}

\begin{tabular}{|l|c|c|c|c|c|c|}
\hline & $\mathbf{2 0 0 3}$ & $\mathbf{2 0 0 4}$ & $\mathbf{2 0 0 5}$ & $\mathbf{2 0 0 6}$ & $\mathbf{2 0 0 7}$ & $\mathbf{2 0 0 8}$ \\
\hline Industry & 2929 & 8101 & 10689 & 9973 & 11447 & 12336 \\
\hline Manufacturing industry & 2916 & 6876 & 8170 & 7588 & 8744 & 9072 \\
\hline $\begin{array}{l}\text { Computers, electrical apparatus, } \\
\text { radio and TV sets, } \\
\text { communications }\end{array}$ & 119 & 434 & 404 & 328 & 479 & 290 \\
\hline Machinery and equipment & 135 & 274 & 348 & 289 & 289 & 386 \\
\hline Metallurgy & 744 & 1981 & 1791 & 1896 & 1923 & 1942 \\
\hline Transport means & 229 & 586 & 1112 & 1065 & 1182 & 1289 \\
\hline Textile, clothing, leather goods & 261 & 860 & 575 & 458 & 468 & 527 \\
\hline
\end{tabular}

Source: Romania National Bank (BNR)

The economic crisis pushed market share downwards and, in 2009, the traditional customers of the textile sector put pressure on to reduce prices. In this respect, many foreign investors in the clothing industry have withdrawn their investment in Romania. Further temporary and permanent closures and company bankruptcies are envisaged by FEPAIUS - the federation of light industry employers - and other employer organizations (ROMCONF, etc). 
FDI originates mostly from European countries, Austria being the main investor in 2008, closely followed by the Netherlands and Germany.

Table 6 - FDI (€m), by origin (2008)

\begin{tabular}{|l|c|c|}
\hline & & Contribution (\%) \\
\hline Total, of which & 48798 & $100 \%$ \\
\hline Austria & 9186 & $19 \%$ \\
\hline The Netherlands & 8402 & $17 \%$ \\
\hline Germany & 7509 & $15 \%$ \\
\hline France & 4294 & $9 \%$ \\
\hline Italy & 3585 & $7 \%$ \\
\hline Greece & 3154 & $6 \%$ \\
\hline Switzerland & 2298 & $5 \%$ \\
\hline Cyprus & 1896 & $4 \%$ \\
\hline Luxembourg & 1107 & $2 \%$ \\
\hline Hungary & 878 & $2 \%$ \\
\hline USA & 869 & $2 \%$ \\
\hline United Kingdom & 727 & $1 \%$ \\
\hline Spain & 604 & $1 \%$ \\
\hline Turkey & 578 & $1 \%$ \\
\hline $\begin{array}{l}\text { Other (countries which invested less than EUR } \\
\text { E500m) }\end{array}$ & 3711 & $8 \%$ \\
\hline
\end{tabular}

Source: Romania National Bank (BNR)

\section{Human capital}

The changes that were made to the 1995 Education Law in 2003 and 2004 significantly improved the legal framework by expanding compulsory education from eight to ten years and introducing some elements of change into the system of the financing of pre-university education, enhancing the autonomy of education units and the role of local authorities.

The number of people with no education at all in 2009 is lower by $70 \%$ compared to 2000 and by $38 \%$ compared to 2005 , while the number of persons attending longterm university increased by $60 \%$ and $31 \%$ respectively. This might be due to the appearance of many private universities, with lower taxes than state-owned universities, with low enrolment requirements and poor academic performance. 
Law No. 76/2000 states that companies who organise training programmes for their employees benefit from subsidies of half their expenditure from the unemployment budget, although in Romania companies invest less $(0.3 \%)$ in job-related training.

However, the number of companies which invest in continuous professional training has increased in the past years. According to the latest data available, the number of companies in manufacturing increased by almost five times, to 5812 in 2005 from 1271 in 1999.

It is worth mentioning that each sector has its specific activity and the differences in gender employment are highly accented in some industries. The textiles industry mostly hires women ( $84 \%$ ) while the metal industry mostly hires men (68 \%). In Romania the gender difference is, overall, not big, but the specificity of each sector brings some disparity.

Europe's competitive advantage in the textiles industry now lies on quality and design, innovation and technology, and high value added products. This requires adequate education and industry-specific training programmes. The education system for the textiles and clothing industry is well-organised in Romania. The country offers five academic centres (in Iaşi, Sibiu, Arad, Oradea and București); R\&D institutes and companies (RDNITL-R\&D National Institute for Textiles and Leather; MATIRO - an R\&D company); and many training centres for masters and technicians. Job-related training includes courses, seminars, workshops and training programmes related to the participant's job. Nevertheless, the Romanian textile industry is still based on the lohn system and one of the main challenges it currently faces remains the growing shortage of skilled resources.

An important aspect of Romania's labour market is the number of immigrants and emigrants. The number of people which have emigrated decreased in the years of economic boom but, in 2009, 10211 people left Romania (up from 8739 in 2008), most of whom (52\%) were aged between 26 and 40 . Romania is mainly a labour exporting country. The same trend is encountered among immigrants: in the period of economic boom the number increased but this dropped as a result of the financial downturn, by $14 \%$ in 2009 , at 8606 people.

\section{International: the sectoral structure of trade}

At the fall of the communist regime, Romania's trade balance was negative. The discrepancy between exports and imports increased exponentially in 2001 and, as of 2005 , reached an amount of $€ 24 \mathrm{bn}$. In 2009 and 2010, the economy was hit by low internal consumption (and also decreased demand), which led to a tighter negative trade balance of $€ 9.8 \mathrm{bn}$ in 2009 ( $€ 4.7 \mathrm{bn}$ in Jan-July 2010).

\section{Trade balance}

The only sector where the balance remained positive is the textiles industry, although the performance of the sector is declining year after year.

The Romanian textile industry started to perish in 2005 due to the increased penetration of Chinese products in the domestic market. This directly affected some SMEs which went bankrupt and the unemployment rate rose, particularly for women. Gov- 
ernment subsidies and reduced export taxes in countries like India, China, Turkey and Vietnam made stronger the trend of low prices for products exported to Romania. Imports from China were at a median price of $\$ 1.70$ per kilo of clothing; Romania produces and exports at a median price of $\$ 32$ per kilo. It is worth mentioning that Romania has the largest quantity of counterfeit goods after Ukraine. Customs are not thoroughly monitored and a major part of the textile and clothing products coming from low-cost production areas enter the country illegally, putting pressure on end-user prices.

\section{Openness indicators}

The different reporting methodologies in foreign trade and production means that only the sectors of textiles, metals and motor vehicle manufacture were used to calculate the openness indicator.

The degree of openness of the economy in the metal and textiles industry is quite high. The destination of textile and clothing goods in 2008 was $82.4 \%$ for the export market and $17.6 \%$ for the domestic market. $85 \%$ of Romanian exports were destined for the European Union, where the main commercial partners were Italy, Germany, France, Greece, UK and Turkey. In the textile and clothing industries, there are more than 1000 joint ventures with foreign partners.

In the metal industry, the percentage of exports as a share of total production has increased significantly (the highest increase was in 2005, by $55 \%$ ): from $5 \%$ in 2000 to $53 \%$ in 2008 . In the manufacture of vehicles, aircraft, vessels and associated transport equipment, $57 \%$ of production was destined for outside the country.

\section{Main trade partners}

The main trading market to which Romania exports its textiles and metal production is the European Union, as a result of easier access and regulations.

In the textiles industry, $94 \%$ of total exports went to the European Union in 2009, the percentage being almost constant through the years.

In greater detail, the production of arms and ammunition is mainly exported to the United States $(42 \%)$. In the rest of the metal industry sectors, the EU is the main trading partner: base metals (61\%); transport equipment (75\%); machinery and electrical equipment ( $80 \%$ ); and optical equipment $(87 \%)$. The same pattern is found in imports, where the main partners on these markets are countries from the European Union, chiefly Italy, Germany, France, United Kingdom and Austria.

It is worth mentioning that China accounted for $15 \%$ of the total quantities of textile imports in Romania in 2009. In regard to the quantities of metals exported from Romania, the highest amount was sent to Asia (2 920342 tonnes), accounting for $56 \%$ of metal industry exports, followed by the EU with $30 \%$.

\section{General business environment}

According to the Global Competitiveness Report (2010-2011), Romania has a worldwide competitive advantage regarding the time and the number of procedures required to start a business, ranking 34th out of 139 countries. In the World Bank's 
ease of doing business index, Romania ranked 55th in 2010, a fall of ten positions from the 2009 position.

The number of days necessary to incorporate a company in Romania, for foreign individuals or legal entities, is approximately ten working days. In order to close a business, the average time spent is about 3.3 years. The number of payments which need to be made yearly to the state budget amount to 113 , leading to 202 hours per year. The total tax rate, as a percentage of profit, is $44.6 \%$ (eastern Europe and central Asia median rate: $43.4 \%$ ). The index measuring the strength of investor protection reached 6 in 2010; the average in eastern Europe and central Asia is 5.5, while it is 5.8 in the OECD.

State aid can be granted to all enterprises (including microenterprises), depending on the type of investment, the sector in which the investment will be implemented and the provisions of the state aid scheme applied for.

Business investment reaches higher than the average levels in the EU, even in 2009, while labour productivity has made significant progress even in the time of crisis (2008). According to the Global Competitiveness Report 2010-2011, Romania has a competitive advantage in terms of labour market efficiency regarding pay and productivity, ranking 33rd in the world (out of 139). However, price convergence is not necessarily a positive fact - on the one hand, it signals real convergence to the eurozone; on the other, as prices grow faster than incomes, purchasing power diminishes and inflationary pressures mount. The progress made by Romania has, nevertheless, been matched by most other new EU member states. Therefore, the catching-up process has been rather slow and the main sources of the competitive disadvantage of the Romanian economy persist. These are the poor quality of infrastructure and the limited level of innovation, which is also a result of low demand for innovative products from unsophisticated customers.

\section{Infrastructure}

The state of basic infrastructure in Romania is still far below EU average standards; considerable gaps will have to be filled with regard to most of the principal indicators. The existing safe water supply systems cover the needs of only $65 \%$ of the population.

In 2006, Romania established a national strategic reference framework and a national strategy report. ${ }^{1}$ As of 2006, Romania was still suffering from the severe underdevelopment of its basic infrastructure caused by decades of under-investment and neglect. Deficiencies in transport and environmental infrastructure today act as a brake on socio-economic development by reducing accessibility for Romanian companies to important markets, discouraging business investment in Romania and limiting the quality of life for a large proportion of its citizens to levels well below EU norms. The maintenance of the existing infrastructure remained under-funded, preserving the inadequate situation of the road and rail networks, while the number of vehicles was on the rise, thus increasing the use of the infrastructure and the traffic-related risks: passenger and freight transport seemed to go up in some sectors, at least prior to the financial crisis. 
There has been very little progress with regard to the length of important public roads. Hence, in 2006-2008 the length of the motorway network went up from $228 \mathrm{~km}$ to $281 \mathrm{~km}$ - just $53 \mathrm{~km}$ in two years - whereas the length of European roads went up in the same interval from $5883 \mathrm{~km}$ to $6073 \mathrm{~km}$, i.e. by $190 \mathrm{~km}$. At the same time, the number of vehicles in operation went up by $27.5 \%$. The increased number of vehicles triggered higher risks related to traffic safety and the number of accidents and victims of accidents rose hugely, by $60 \%$ in the same period. Most towns and cities along the European road network lack ring roads, so the traffic is directed through the centres. In addition, many villages are crossed by public roads.

The insufficiency of funds for the maintenance and rehabilitation of the rail infrastructure persisted in 2006-2009, leading to a continuous degradation of the rail infrastructure (reflected, for instance, in speed restrictions), including the rolling stock. As a result, the ability to provide modern and high quality services remains poor, as is the safety of railway traffic. Even if the effects of the economic crisis experienced in 2009 are put aside, the volumes of railway passengers and freight transport dropped in 2006-2008, as follows: freight traffic in thousand tonnes $/ \mathrm{km}$ went down by $9.3 \%$ while the number of passengers decreased by $17.2 \%$. This tells us that there is an increasing need for higher quality services that has to be met in order to reach the objective of higher market share.

Between 2006 and 2008, freight shipping, which was low compared to older member states, saw a minor increase of only $0.2 \%$, but is still at a reduced level.

In 2006-2008, passenger traffic in Romanian airports continued to rise significantly, from 5.49 million passengers to 9.07 million passengers; this increase could be seen almost fully in the international airports: Henri Coandă - Bucureşti; Aurel Vlaicu Bucureşti; Traian Vuia - Timişoara; and Cluj-Napoca. The main investment programmes financed from domestic sources which are aimed at increasing airport capacity by three million pax/year were planned for these four airports. Of these, the works were completed at the arrivals/departures terminal of Cluj-Napoca (additional capacity of 0.5 million pax/year). The other investments, to be completed by 2015 , will ensure the necessary capacity of Romanian airports.

In this perspective, Romania has to improve its infrastructure which will lead to high demands on the construction industry and the metal industry.

\section{Promotion of investment}

At national level, the volume of state aid has varied significantly, in line with economic events. Thus, in 2006 was registered a higher level due to increased restructuring and privatization of state - owned companies in that period and that was the last year when state aid schemes and individual state aid could still be approved by the Competition Council at a national level.As a share of GDP, national state aid has had a continuous downward trend from $1 \%$ in 2005 to $0.56 \%$ in 2007 , due to its higher growth compared to growth of state aid. 
Table 7 - State aid (lei, m)

\begin{tabular}{|l|l|c|c|c|c|}
\hline & & $\mathbf{2 0 0 4}$ & $\mathbf{2 0 0 5}$ & $\mathbf{2 0 0 6}$ & $\mathbf{2 0 0 7}$ \\
\hline $\begin{array}{l}\text { State aid (mn lei) - except agriculture, } \\
\text { transportation and fishing }\end{array}$ & 6510497 & 2860438 & 3383648 & 2248763 \\
\hline $\begin{array}{l}\text { Manufacturing } \\
\text { industry }\end{array}$ & thousand lei & 3052508 & 358484 & 386826 & 144799 \\
\cline { 2 - 6 } & share (\%) & 46.89 & 12.53 & 11.43 & 6.44 \\
\hline $\begin{array}{l}\text { Research and } \\
\text { development }\end{array}$ & thousand lei & 58501 & 54960 & 110180 & 104778 \\
\cline { 2 - 6 } & share (\%) & 0.90 & 1.92 & 3.26 & 4.66 \\
\hline $\begin{array}{l}\text { Environmental } \\
\text { protection }\end{array}$ & thousand lei & 43770 & 28982 & 40075 & 17485 \\
\cline { 2 - 6 } & share (\%) & 0.67 & 1.01 & 1.18 & 0.78 \\
\hline \multirow{2}{*}{\begin{tabular}{l} 
Job creation \\
\cline { 2 - 6 }
\end{tabular}} & thousand lei & 21571 & 8403 & 3624 & 1004 \\
\hline share (\%) & 0.33 & 0.29 & 0.11 & 0.04 \\
\hline $\begin{array}{l}\text { Commerce, } \\
\text { construction, } \\
\text { services, mining } \\
\text { industry }\end{array}$ & thousand lei & 782493 & 598085 & 701881 & 111539 \\
\cline { 2 - 6 } & share (\%) & 12.02 & 20.91 & 20.74 & 4.96 \\
\hline $\begin{array}{l}\text { Services of general } \\
\text { economic interest }\end{array}$ & thousand lei & 1511000 & 1271155 & 1616064 & 1429783 \\
\cline { 2 - 6 } & share (\%) & 23.21 & 44.44 & 47.76 & 63.58 \\
\hline
\end{tabular}

Source: Ministry of Economy

By their nature, there are two types of state aid - those involving budget expenditure; and those regarding the waiver of a portion of state revenues. The weight of state aid funds related to the waiver of state revenues was reduced during 2005-2007, so that budget expenditures in 2007 held a $94.89 \%$ share of total national state aid compared to $17.99 \%$ in 2004 . Reversing the ratio of the two categories is due to the abrogation of OUG No. 40/2002 in 2005 regarding the recovery of budgetary arrears, including the steel industry, under which a number of economic agents were exempted in 2004 from the payment of interest rates, increases and penalties for late payment. Most spending $(90.98 \%)$ was made in the form of grants, allowances, bonuses, loans at subsidised rates and other amounts granted mainly to traders who have been entrusted with the provision of public services of general economic interest and subsidies granted to the mining industry (National Hard Coal Company Petroşani).

State aid granted to manufacturing industries decreased sharply in 2005-2007, from $46.89 \%$ in 2004 to $6.44 \%$ in 2007 , following the reduction of the direct intervention of the government in the Romanian economy and due to the registered increases in manufacturing industries regarding competitiveness and labour productivity. Most of the aid was designed to achieve some horizontal objectives (81.08\% in 2007) as well as the restructuring of enterprises and support for the small and medium enterprise sector. No aid was given towards sectoral objectives in 2006 or in 2007. 
In 2005-2006, however, state aid regarding the waiver of a portion of state revenues held a larger share of total state aid for manufacturing (71.68\% in 2005 and $69.81 \%$ in 2006) as a result of the tax incentives granted to restructuring firms in difficulty. In 2007, once Romania had become part of the EU, the direct application of Community legislation has reduced tax incentives and led to less harmful state aid with regard to the nature of spending. In this context, in 2007, the share of state aid regarding the waiver of state revenues as a percentage of total state aid in manufacturing was only $38.3 \%$ while budget expenditures (subsidies, allowances, bonuses, interest subsidies, other earnings, grants and state equity participation) accounted for the other $61.7 \%$.

The trends in state aid in the manufacturing sector indicates that aid providers have sought to reduce state involvement in the economy, especially in periods of growth, when the available budget goes mostly towards state aid for regional development, job creation, research and development and innovation.

\section{Labour market}

Romania has benefited from robust growth for most of the decade, but progress towards achieving the objectives of the Lisbon Agenda has not been as great as expected. The labour market faces major gaps in numerical terms, but also in terms of competences, problems which co-exist with low participation rates and with an excess of labour supply in declining sectors (mainly agriculture). Labour market conditions in Romania are particularly difficult, although the unemployment rate is not necessarily high compared with the EU average, but unemployment is asymmetric, affecting especially the unskilled, the young and the elderly. This raises questions about the capacity of the education system in Romania and the versatility of continuing education and training to create a competitive workforce.

The negative growth rate of the Romanian population, which began in the 1990s, has already reduced the population by $10 \%$. To this outcome must be added labour migration, estimated at between one and two million people from the population of working age, although most of these are short-term. Most migrants are still included in the labour market statistics as inactive, but absent from the labour market in Romania. This makes achieving the Lisbon goals more difficult and could be partly responsible for the slow progress in employment rates in Romania.

Table 8 - Unemployment rate - annual average

\begin{tabular}{|c|c|c|c|c|c|c|c|c|c|}
\hline $\mathbf{1 9 9 1}$ & $\mathbf{1 9 9 2}$ & $\mathbf{1 9 9 3}$ & $\mathbf{1 9 9 4}$ & $\mathbf{1 9 9 5}$ & $\mathbf{1 9 9 6}$ & $\mathbf{1 9 9 7}$ & $\mathbf{1 9 9 8}$ & $\mathbf{1 9 9 9}$ & $\mathbf{2 0 0 0}$ \\
\hline 1.8 & 5.4 & 9.2 & 11.0 & 10.0 & 7.8 & 7.5 & 9.3 & 11.4 & 11.2 \\
\hline $\mathbf{2 0 0 1}$ & $\mathbf{2 0 0 2}$ & $\mathbf{2 0 0 3}$ & $\mathbf{2 0 0 4}$ & $\mathbf{2 0 0 5}$ & $\mathbf{2 0 0 6}$ & $\mathbf{2 0 0 7}$ & $\mathbf{2 0 0 8}$ & $\mathbf{2 0 0 9}$ & $\mathbf{2 0 1 0 *}$ \\
\hline 9.0 & 10.2 & 7.6 & 6.8 & 5.8 & 5.4 & 4.3 & 4.0 & 6.3 & 7.8 \\
\hline
\end{tabular}

*2010 annual average comprises the first 9 months of the year 
The problems faced by the labour market during the boom resulted in higher wage increases than productivity and, as a consequence, further eroded Romania's external competitiveness. At the onset of the crisis, wages from both the public and the private sectors had become too high to cope with falling demand, forcing employers to adjust their workforce and therefore temporarily reducing pressure on the labour market.

Skills that equip graduates of the education system often appear to be decoupled from the expectations of employers. A better adaptation of the curricula to the labour demand is, therefore, imperative. Opening employment market segments for foreign workers should also be considered to fill the gap between current workforce supply and demand positions. Policies should also focus on the poor and the disabled.

The informal economic sector is large, approximately $20 \%$ of GDP, and may also explain the reduced number of formal employees and the paradox of unemployment: the grey economy seems to provide a large number of low-paid jobs mainly to unskilled people who cannot find jobs in the formal economy.

Romania has, in recent years, passed a series of reforms to strengthen labour market flexibility, increase participation and create sustainable jobs. This includes revising the Labour Code, placing more emphasis on active labour market policies and improving the business environment to reduce the costs for corporate transactions, including by simplifying business registration. The effects have been beneficial and have led to an increasing employment rate and a reduced unemployment one. Otherwise, we should not miss the safety valve of the massive emigration of workers, helping to keep unemployment relatively low.

\section{Environmental and energy policies}

Romania has successfully implemented all European policies and directives regarding the environment, according to the established schedule (horizontal legislation and regulations, air quality, industrial pollution control, water quality, the protection of nature, hazardous substances, climate change, noise).

Several important events have marked out the development of the energy sector in Romania. First was Romania's accession to the European Union, the implementation of the relevant EU acquis communautaire - in particular the first and second package creating a unique internal energy market - and the completion of programme policy documents for long-term energy, i.e. the National Strategy Regarding Energy Efficiency, in August 2003, followed by the Action Plan on Energy Efficiency (2007-2010) and the Strategy for Renewable Energy 2007-2020. A significant impact on trends in the Romanian energy sector will be the third European package, creating a single internal electricity and natural gas market within the EU. The reform of the electricity market implemented by the government in early 2010 is another significant event which will have a major impact on the Romanian energy sector.

Romania has very limited reserves of oil and natural gas and relatively large reserves of coal. According to the latest energy statistics published by the EU, currently around $30 \%$ of Romania's primary energy demand is covered by imports, but this dependence will become more acute in terms of the exhaustion of domestic production, even under changes introduced in the energy mix of the larger-scale use of renewable energy resources. Studies estimate that Romania has relatively significant resources of 
renewable energy. However, technological limitations, economic efficiency, the variability of resources and environmental restrictions mean that its exploitable potential, however, is lower than the theoretical. Romania currently has an installed capacity of electricity generation of about $20 \mathrm{GW}$ in coal-fired power plants, oil and gas, and the Cernavoda nuclear power plant, as well as a capacity of over $10 \mathrm{MW}$ through its hydro plants.

Currently, Romania is subject to the European Commission's infringement procedure regarding the liberalisation of the natural gas market. The legal framework has not properly been implemented and Romania does not have the possibility to export the natural gas produced internally. Also, the pipeline network relating to neighbouring countries is under-developed, while most natural gas imports come from Russia and, consequently, at an inflated price. Some pipelines are in the plan to be built, but the process is slow (for example: Nabucco). Recently, the Arad-Szeged pipeline, an alternative to gas from Gazprom, was officially inaugurated although for now, because of the Romanian laws, it operates in only one direction (i.e. for the import of gas).

To support the development of renewable resources, Romania has chosen to implement a system of green certificates. These are distributed to renewable energy producers and then traded on a secondary market with lower price limits than those set by the law.

In order to reduce the emissions of greenhouse gases, Romania has adopted a national plan to distribute emission allowances, but has not been active in negotiating on the international market, resulting in excess emissions in terms of greenhouse gases. Romania has not been very active in the implementation of other pollution control mechanisms, for example, projects within the Clean Development Mechanism (CDM).

Manufacturing industries account for $17.5 \%$ of total energy consumption. Environmental protection expenses have increased in the past years: available data indicate, in 2008 , an increase of $161 \%$ on the 2005 level across the whole country (specialised and non-specialised producers and public administration), while major investments have been carried out for soil and groundwater, increasing by $284 \%$ in the same timeframe. Fewer investments, however, have been made in improving noise and vibration pollution (up $4 \%$ ).

Quantities of dangerous waste generated in Romania have decreased, in terms of tonnage, by $81 \%$ in 2007 compared with 2003, although waste management is decreasing. Therefore, the amount of dangerous waste recovered decreased by $15 \%$, while eliminated waste decreased by $93 \%$ over the same period. Dangerous waste generated by the textile and clothing industry increased significantly (over six times), although, waste elimination has been a success, reaching $85 \%$ of total generated waste. The metal industry reduced the quantity of dangerous waste generated by $67 \%$, managing also to increase the volume of waste recovered out of total waste generated (from $38 \%$ in 2003 to $49 \%$ in 2007).

However, according to an investigation conducted in 2005, out of the total number of wastewater treatment installations, only $37.6 \%$ were functioning according to required standards. The result is that almost $71 \%$ of the water coming from the principal polluting sources is being discharged into natural recipients, especially rivers, untreated or insufficiently treated. The main sources of used water were electric and thermal 
power production (51\%); public utilities, especially sewage systems (36\%); and other activities $(13 \%)$. The latest investment programmes implemented by the state in 2006-2008 brought only minor advancements, and then through investments promoted under European-funded programmes, or programmes financed with national budget or foreign loans. It remains necessary to raise the implementation of environmental infrastructure investment further up the agenda of this programme period.

\section{Summary and conclusions}

Romania's economy, in terms of GDP, has increased since the pre-accession terms of entry to the European Union started to be implemented. ${ }^{2}$ In the last decade, the average GDP growth rate was $6.2 \%$, fuelled mainly by unsustainable development. The pro-cyclical fiscal measure lead to a high budget deficit and the bubble burst when the global economic crisis started affecting Romania. The moment came in the middle of presidential elections, when there were major disagreements between the parties. The disagreements continued after the elections and, therefore, the government has delayed the actions necessary to mitigate the financial downturn. Faced with a continuous increase in the budget deficit, the state contracted a $€ 20 \mathrm{bn}$ loan with the IMF, thus managing to avoid any potential shortfalls in financing its external and internal deficits. In order to meet the loan agreements, the government took a seies of unpopular austerity measures, including: reducing wages in the public sector by $25 \%$; making 115000 layoffs in the budget sphere; and increasing VAT from $19 \%$ to $24 \%$.

During the period of communism, the country was highly industrialised although investments were not allocated efficiently. The metal and textiles industries are traditional activities in Romania, with some regions in the country - workplaces, economic development - dependent on activity in the factories. In the last decade, major changes have occurred and different actions needed to be taken. The metal industry has just emerged from a rigorous restructuring plan, while the textile industry needs a solid strategy as it is facing serious problems due to the effects of cheap labour from eastern countries, i.e. China and India.

Before the restructuring programme took place, the big companies in the metal industry which were owned by the state were working at dumping prices and had therefore started to be unproductive.

A large number of loss-making enterprises were kept alive through government interventions, which sheltered them from the rigours of market discipline and prevented them from adjusting to an increasingly competitive business environment. Delayed restructuring and insistence on unrealistic conditions for privatisation in relation to market requirements caused a severe depreciation of assets in many enterprises and wiped off the competitive advantages that they might originally have had. The actual worth of manufacturing equipment that was made redundant as a result of restructuring and privatisation is hard to estimate, but it will suffice to note that, from 2000 to 2007 , Romanian exports of scrap iron averaged two million tonnes a year. It is noteworthy that some sectors (textiles, electrical equipment, shipbuilding) underwent deeper struc- 
tural adjustments as a result of rapid privatisation and were able to attain a reasonable level of profitability.

The European Commission has just released its latest monitoring report on the restructuring programme of the metal industry and declared the extent of its achievement to be 'acceptable', as the economic crisis has had a severe impact on operations with the consequence that the final regulations have not been met. Key global players entered the Romanian market, providing an element of support and confidence in the restructuring of the steel mills and ensuring value added in the industry, as well as know-how and a portfolio of clients. Due to the transitional and restructuring efforts, productivity in the metal industry increased, benefiting also from a skilled and well-trained workforce. More than one-half of production is exported in the metal industry, while the manufacture of vehicles, aircraft, vessels and associated transport equipment sees $57 \%$ of production destined for markets outside the country. Romania is also highly dependent on raw materials. The financial crisis had an enormously negative impact on the industry (all studied sectors less the textiles and clothing industry), companies being forced to lay-off workers (reduced to 427500 in 2010 from 569705 in 2008), reduce production, close plants or reschedule planned investments.

The Romanian textiles and clothing industry is based on the lohn system - businesses within the lohn system are focused on producing items using unskilled labour which is considered cheap internationally. The raw materials are imported, processed and then exported again. The system worked until 2005, when China, with a much cheaper workforce, gained access to the World Trading Organisation. The textile industry now faces serious problems since a major part of the sector's revenue was met from exports; $90 \%$ of total production is exported and, with poor value added, Chinese merchandise will be preferred. Internally, in Romania, there is a lack of powerful local brands and here, consumers, in the main, prefer imported cheap products. To this extent, there is an acute need to develop a rigorous strategy.

A national and important problem that Romania is facing is corruption. According to the Competitiveness Report 2010-2011 (World Economic Forum), Romania ranks 77th (out of 139 - the lowest rank) in problems of ethics and corruption, reaching 84th place in the diversion of public funds and 57th in irregular payments and bribes. In the transparency of government policy-making, Romania was ranked 137th, therefore leading to public trust in politicians reach 116th position.

Even if quota removal and EU accession seem to be having little short- or mediumterm impact on Romanian industry, sectoral and company strategies need to become more focused on long-term issues.

Concerning the textile industry, the main focus should be on reducing the lohn system, while greater attention should be paid to the domestic market, which will become more attractive in the future: creating national brands is a way of becoming less dependent on external orders. This involves, for example, highly specialised products, more effort in research and development and expert consultancy. The textiles, clothing and footwear sector is rather fragmented, due to the high presence of SMEs, so networks should be built for identifying suppliers, potential beneficiaries and retail outlets, and for making use of e-commerce facilities. 
Concerning the metal industry, special attention should be paid to R\&D investment, especially in terms of discovering new technologies to reduce dangerous waste and $\mathrm{CO}_{2}$ emissions. Capacity needs to be developed around innovation that could help manage the sustainability of the sector, in particular with respect to ambitious EU objectives on climate change.

The way forward is to invest in research, development and innovation in order to increase value added in production. Companies will have to shift their strategic focus and try to move further up the value chain. Companies will, therefore, have to invest more in human resources and pay more attention to employee motivation and salary policies. It is also important to introduce social, health \& safety standards and to develop an ethical perspective as part of the investment in human resources. Both sectors also need to have a more efficient bipartite dialogue, greater backing and a stronger lobby for specific programmes and strategies.

In order to achieve full sustainable viability, and to help the industries cope with any future market uncertainties, continuous implementation is required in terms of cost reduction strategies and the development of coherent strategies for the future. 